\title{
The Influence Of Using Dakon Mathematics Media On Student Learning Outcomes In Class IV SD Bone District
}

\author{
Muh Idris Djafar ${ }^{1}$, Muliadi $^{2}$, Bahar $^{3}$ \\ \{idrispgsd@gmail.com ${ }^{1}, \underline{\text { muliadi@gmail.com² }}$, baharmat@yahoo.co.id $\left.{ }^{3}\right\}$ \\ ${ }^{1,2,3}$ Universitas Sawerigading Makassar, Indonesia
}

\begin{abstract}
The purpose of this study was to determine the use of mathematics media media to the learning outcomes of fourth grade elementary school students in Bone Regency and then to find out the significant influence of the use of media media to mathematics learning outcomes of fourth grade elementary school students in Bone Regency. Quantitative approach to the type of research True-Experimental Design, a random sampling technique from a particular population. The research variables consist of two, namely the dakon Media as the independent variable (X) and Learning Outcomes as the dependent variable (Y). The research design was the Pretest-Posttest Control Group Design Matching Design. The population in this study was all fourth grade students in Tanete Riattang District, Bone Regency, amounting to 33 elementary schools. The results of the study showed that the learning of the mathematics media media took place effectively, evidenced by an increase in mathematics results. The conclusion of the study was that there was a significant influence on the use of the media of mathematics to the learning outcomes of fourth grade elementary school students in Bone Regency.
\end{abstract}

Keywords: Dakon media, mathematics learning outcomes.

\section{Introduction}

Learning outcomes are very important in education and can be seen as one measure of student success in education at school. Learning media is a tool that serves to explain learning that is difficult to explain verbally so that communication will take place effectively between teacher and students and can provide stimulation for students in the learning process. In line with the opinion according to Gagne (Sadiman, 2012: 6) argues that "the media are various types of components in the student environment that can stimulate them to learn". This opinion was made clear by Briggs (Hamzah, 2014: 122) that "the media are all physical forms that can convey messages and stimulate students to learn. While Arief S. Sadiman, et al (2012), suggest that media comes from the Latin word meaning the intermediary or introductory media is the intermediary between the message between the recipient and the message giver.The media used in this study is the dacon learning media which is a learning medium which is a modification of one of Indonesia's traditional games, namely congklak (Linguistika, 2011).

The benefits of using media according to Kemp and Dayton (Asyad, 2014: 25) suggest as follows: (1) Submission of lessons becomes more standard. Every student who sees or hears the presentation through the media receives the same message, (2) Learning bias is more interesting. Media can be associated as attracting attention and keep students awake and attentive, (3) Learning becomes more interactive by applying learning learning theories and 
psychological principles accepted in terms of student participation, feedback, and reinforcement, (4) Length of learning time what is needed can be shortened because most media use a short time in delivering messages, (5) The quality of learning outcomes can be improved if the integration of words and images as learning media can communicate elements of knowledge in a well organized way, (6) Learning can be given when and where desired or needed especially if learning media are designed for individual use, (7) Students' positive attitudes towards what they are learning and towards the learning process can be improved, (8) The role of the teacher can change towards a more positive direction, the teacher's burden to explain repeatedly ken Learning content can be reduced

While the results of learning mathematics according to Bruner (in Kristina, 2014) "Learning about mathematical concepts and structures contained in the material being studied, and looking for the relationship between concepts and structures of Mathematics". The same thing with Namawi's opinion (Susanto, 2013) states that learning outcomes can be interpreted as the level of success of students in learning subject matter in school and expressed in scores obtained from test results regarding a number of specific learning materials. The factors that influence according to (Susanto, 2013: 12) are Internal Factors, namely factors that originate from within the students themselves, which influence their learning ability. Internal factors are intelligence, interests, attention and others. While external factors, namely factors that originate from outside themselves students that affect learning outcomes. External factors are family, school and community

\section{Methodology of Research}

The research design used is quantitative research conducted is a True-Experimental Design. The sample used for the experimental class or the control class is taken randomly from certain participants. The research variables consist of two, namely the dakon Media as the independent variable (X) and Learning Outcomes as the independent variable (Y). The research design used in this study was the Design Matching Pretest-Posttest Control Group Design. The design of random sampling (randomized control design of pretest-posttest control. The population in this study was fourth grade students in Tanete Riattang District, Bone Regency which produced 33 elementary schools.

\section{Results}

Based on the results of data analysis obtained by these data, it can be concluded at my meeting that the learning process carried out using the mathematics media media obtained a percentage of effectiveness of $70.9 \%$ according to the effective category. While in the meeting II the learning process carried out obtained an effectiveness level of $83.3 \%$ which is in the very effective category.

Table 1. Description of Statistical Data

\begin{tabular}{lllll}
\hline \multirow{2}{*}{$\begin{array}{l}\text { Descriptive } \\
\text { statistics }\end{array}$} & \multicolumn{4}{l}{ Statistical Value } \\
\cline { 2 - 5 } & $\begin{array}{l}\text { Pretest } \\
\text { Experiment }\end{array}$ & $\begin{array}{l}\text { Pretest } \\
\text { Control }\end{array}$ & $\begin{array}{l}\text { Posttest } \\
\text { Experiment }\end{array}$ & $\begin{array}{l}\text { Posttest } \\
\text { Control }\end{array}$ \\
\hline Subject & 26 & 26 & 26 & 26 \\
\hline Mean & 56,31 & 54,46 & 77,54 & 70,50 \\
\hline Std. Deviation & 6,49 & 7,84 & 10,37 & 9,24 \\
\hline
\end{tabular}


Based on table 1, it is known that the standard deviation of the pretest value of the experimental class and the control class is quite diverse. While the variants of the data show that the results of the experimental and control pretest analysis are very diffuse. Likewise what happened in the posttest of the experimental class and the control class, but showed an increase in each of the experimental class and the control class before and after treatment, this can be seen an increase in the experimental mean value of 21.23 , whereas in the control class before and after the treatment has increased of 16.04.

If the scores of the experimental class learning outcomes after treatment are grouped into 5 categories, then the percentage is in the good category

As for the description of the media of mathematical data on learning outcomes during the learning process, the experimental class students who use the media of mathematics seem more interested in paying attention to the material delivered by researchers. In addition, students are more responsive in understanding the material and more active in learning compared to the control class. The media of mathematics can be said to be more effective in creating a learning atmosphere that is liked by students so that students prefer to learn and get optimal results. In line with the opinion of Hamalik (Ahmad, 2007: 5), which states that the media is a tool used to be effective in the learning process. So that the use of the media of mathematics has a positive impact on learning, for example in increasing student interest in learning so that students become more active in learning. Learning also becomes easier, more fun for students because this media wants to be tried by most students. Agree with the research of Kristina Mardiana (2014) which states that the use of the media of mathematics mathematics increases student activity and learning outcomes. The implementation of learning using the media of mathematics is effective because the percentage of experimental class categories has increased. So that this can affect student learning outcomes in mathematics in high school students at SD Negeri 9 Manurungnge, Bone Regency

Furthermore, the effect of the media of mathematics mathematics on student learning outcomes from the results of tests that have been carried out where the results of the pretest of the experimental class and the control class is known that does not have a significant difference with a significance value of $0.05>0.838$. While the average value of the results of the experimental class posttest and control class with a significance value of $0.05>0.031$. Shows that there are significant differences. So that the results of the study are that there are significant differences from the class that gets treated using the media of mathematics with those who do not use the media of mathematics. In line with the results of Hidayat's research (2016), it was suggested that the posttest rat score of the experimental class was higher than the control class and had an influence in the medium category.

\section{Conclusion}

Based on the results of the study, it can be concluded that the learning process by using the media of learning mathematics mathematics is effective, the effectiveness is evidenced by an increase in the results of the learning process. There is a significant influence. The conclusion of the study was that there was a significant influence on the use of the media of mathematics to the learning outcomes of fourth grade elementary school students in Bone Regency 


\section{References}

Arsyad, Azhar. 2014. Media Pembelajaran. Jakarta. RajaGrafindo Persada.

Aspriliana,Rizkia.2018. Pengaruh Media Dakon Bilangan Terhadap Hasil Belajar FPB dan KPK Siswa SDN 34 Pontianak. JIPP, Vol. 7 (3) :6-7. http://jurnal.untan.ac.id/index.php/jpdpb/article/viewFile/24429/75676576042

Gafur, Abdul. 2012. Desain Pembelajaran. Yogyakarta. Penerbit Ombak

Hamzah, Nina Lamatenggo. 2014. Teknologi Komunikasi dan Informasi Pembelajaran. Jakarta. Bumi Aksara.

Hidayat, Asep. 2016. Pengaruh Penggunaan Alat Peraga Dakon Matematika (Dakota) Terhadap Hasil Belajar Matematika Siswa. Skripsi. Jakarta. Fakultas Ilmu Tarbiyah dan Keguruan. Universitas Islam Negeri Syarif Hidayatullah.

Kristina Mardiana. 2014.Peningkatan Aktivitas Dan Hasil Belajar Siswa Menggunakan Dakon Bilangan Kelas IV SDN 06 jurnal pendidikan dan pembelajaran UNTAN. https://www.neliti.com/id/journals/jurnal-pendidikan-dan-pembelajaran-untan

Kunandar. 2013. Penilaian Autentik. Jakarta. RajaGrafindo Persada.

Linguistika,Yulia dan Ikfan Febriyana. 2011. Permainan Dakonmatika Sebagai Media Pembelajaran Matematika Topik Faktor Persekutuan Terbesar (FPB) dan Kelipatan Persekutuan Terkecil (KPK) bagi Siswa Sekolah Dasar. Makalah. Disajikan dalam Seminar Nasional Matematika dan Pendidikan Matematika. Yogyakarta. 3 Desember 2011.

Mahmud. 2011. Merode Penelitian Pendidikan.Bandung. Pustaka Setia.

Mardiana, Kristina. 2014. Peningkatan Akrivitas dan Hasil Belajar Siswa Menggunakan Dakon Bilangan Kelas IV SDN 06. Skripsi. Pontianak. Universitas Tajung Pura.

Nunu Mahnun. 2012. Kajian terhadap Langkah-langkah Pemilihan Media dan Implementasinya dalam Pembelajaran. Jurnal Pemikiran Islam; Vol. 37, No. 1 JanuariJuni 2012. http://ejournal.uin-suska.ac.id/index.php/Anida/issue/view/86/showToc

Purwanto, Ngalim. 2010. Prinsip dan Teknik Evaluasi Pengajaran. Bandung. Remaja Rosdakarya

Sadiman Arief, dkk. 2012. Media Pendidikan. Jakarta. Rajagrafindo Persada.

Siregar,syofian. 2013. Metode Penelitian Kuantitatif. Jakarta. Prenadamedia Group.

-----. 2014. Statistik Parametrik Untuk Penelitian Kuantitatif. Jakarta. Bumi aksara.

Sukardi. 2013. Metodologi penelitian pendidikan. Jakarta. Bumi Aksara 